\title{
Molecular analysis of desiccation tolerance in barley embryos and in the resurrection plant Craterostigma plantagineum
}

\author{
JM Alamillo, R Roncarati, P Heino, R Velasco, D Nelson, R Elster, \\ G Bernacchia, A Furini, G Schwall, F Salamini, D Bartels*
}

Max-Plank-Institut für Züchtungsforschung, Carl von Linné Weg 10, D-50829 Cologne, Germany

(Received 7 July 1993; accepted 15 September 1993)

\begin{abstract}
Summary - Two experimental systems, developing barley embryos and the desiccation-tolerant plant Craterostigma plantagineum, have been used to isolate cDNA clones specifically expressed in dehydrated tissues. Sequence analysis revealed that most of the isolated cDNA clones show homologies to previously reported genes. Most of the desiccation-induced genes in Craterostigma encode polypeptides with substantial homologies to proteins expressed during late embryogenesis in many higher plants. The expression of these genes is induced by abscisic acid treatment in leaves and in undifferentiated callus tissue. Subcellular localization of the corresponding proteins shows that most are cytoplasmic and that 3 dehydrationinduced proteins are localized in the chloroplast. In developing barley embryos, some of the cDNA clones are related to genes encoding enzymes involved in sugar metabolism. One of these clones shows high homology to the animal aldose reductases involved in the synthesis of the osmolyte sorbitol. The protein encoded by this clone has been over-expressed in Escherichia coli and the purified protein shows aldose reductase activity.
\end{abstract}

abscisic acid/dehydration/gene expression/Lea-type proteins/water stress

Résumé - Analyse moléculaire de la tolérance à la dessiccation d'embryons d'orge et de la «plante à résurrection" Craterostigma plantagineum. Deux systèmes expérimentaux, à savoir les embryons d'orge et la "plante à résurrection" Craterostigma plantagineum, ont été utilisés pour isoler des clones d'ADNc exprimés de manière spécifique dans les tissus déshydratés. L'analyse de séquence de ces clones révèle, dans la plupart des cas, une homologie avec des gènes déjà connus. Chez Craterostigma plantagineum, la plupart des gènes induits par la dessiccation codent pour des polypeptides similaires aux protéines exprimées durant l'embryogenèse tardive de plusieurs plantes supérieures. L'expression de ces gènes est induite par des traitements à I'ABA sur des feuilles ou des cals. Les protéines induites par la déshydratation sont pour la plupart localisées dans le cytoplasme mais 3 d'entre elles sont chloroplastiques. Dans les embryons d'orge en développement, certains de ces clones d'ADNc présentent une homologie avec des gènes codant pour des enzymes impliquées dans le métabolisme des glucides. Un de ces clones montre une forte homologie avec le gène de l'aldose réductase animale qui intervient dans la synthèse du sorbitol. La protéine codée par ce clone a été surexprimée chez $\mathrm{E}$ coli. Après purification, cette protéine possède une activité aldose réductase.

ABA / déshydratation/expression des gènes/protéines de l'embryogénèse tardive/tolérance à la dessication

\footnotetext{
*Correspondence and reprints
} 


\section{INTRODUCTION}

Adaptation to cellular dehydration is one of the most important characteristics that determines the distribution and yield of cultivated plants. Most plant species are able to survive mild water stress but prolonged exposure to stress usually leads to irreversible damage of the cellular structures.

In only a few cases is an organism able to withstand severe dehydration. This ability has been acquired, for example, by baker's yeast Saccharomyces cerevisiae, some soil nematodes and mosses like Tortula ruralis. In higher plants the ability to survive water loss is normally limited to embryos in developed seeds and to the small group of resurrection plants, which exhibit desiccation tolerance throughout the whole life cycle: Resurrection plants can loose more than $90 \%$ of their water, stay in anhydrobiotic state and resume active life a few hours after water becomes available again (Gaff, 1971, 1981; Bartels et al, 1990). This survival requires a particular cellular conditioning, which, in the case of embryos, is developmentally regulated and switched on during the embryo maturation; in resurrection plants the conditioning is induced during the dehydration process itself. These 2 systems provide an interesting possibility to study and isolate components that are involved in the development of desiccation tolerance.

We have chosen 2 experimental systems for the molecular analysis of desiccation tolerance: the resurrection plant Craterostigma plantagineum and the developing barley embryo. Moreover, the use of Craterostigma as a model system offers the advantage that the callus tissue obtained from Craterostigma leaves can exhibit desiccation tolerance after treatment with the phytohormone abscisic acid (ABA) (Bartels et al, 1991). Thus it is possible to study both undifferentiated and differentiated tissues from the same plant species.

Both in barley embryos and in Craterostigma, the development of desiccation tolerance is correlated with increased concentrations of ABA (Bartels et al, 1990) and this hormone is presumably involved in the induction of gene expression during turgor loss.

We have previously reported the isolation of a number of cDNA clones corresponding to transcripts that are induced during desiccation or ABA treatment (Piatkowski et al, 1990; Bartels et al, 1991, 1992, 1993). In this article we will summarize some regulatory features of corresponding genes in Craterostigma and in barley embryos. Furthermore, the structural characteristics of some of the major gene products will be discussed.

\section{RESULTS AND DISCUSSION}

The dehydration process in both the resurrection plant and barley embryos is correlated with major changes in the mRNA and protein profiles (Bartels et al, 1988, 1990). The major proteins present in the dehydrated state of both organisms are qualitatively, at least in part, similar.

To isolate transcripts relevant to desiccation in both systems, cDNA libraries were constructed using poly $\mathrm{A}^{+}$RNA from desiccated Craterostigma leaves and developing barley embryos as templates. These cDNA libraries were differentially screened to obtain clones corresponding to transcripts specifically expressed in dehydrated tissues.

\section{Craterostigma plantagineum}

A large number of cDNA clones corresponding to transcripts induced during dehydration were isolated. A characteristic feature of these transcripts is their rapid induction during the first hours of water loss (Bartels et al, 1990).

The majority of the cDNA clones could be classified into 11 families by crosshybridization. Representative clones of these groups were selected for further analysis, including sequence determination, tissue and cellular localization of the encoded proteins and the expression of the corresponding genes under stress conditions.

Sequence analysis of representative clones revealed that most of them showed significant homologies to previously published genes (table l). Most of the homologies were found to different late embryogenesis abundant (Lea) genes expressed in seeds of higher plants (Galau et al, 1986). 
Table I. Homologies of isolated Craterostigma cDNA clones.

\begin{tabular}{|c|c|c|c|}
\hline $\begin{array}{l}\text { Craterostigma } \\
\text { cDNA clone }\end{array}$ & Encoded protein & Homology ${ }^{\mathrm{a}}$ & References ${ }^{b}$ \\
\hline $\begin{array}{l}\text { pcC6-19 } \\
\text { pcC27-04 } \\
\text { pcC86 } \\
\text { pcC126 } \\
\text { pcC76 }\end{array}$ & $\begin{array}{l}\text { dsp } 16 \\
\text { dsp } 14 \\
- \\
- \\
-\end{array}$ & $\begin{array}{l}\text { Group } 2 \text { Lea: } \\
\text { rab } 16 \text { (rice) } \\
\text { dehydrin (barley) } \\
\text { rab } 17 \text { (maize) } \\
\text { Lea D11 (cotton) } \\
\text { radish }\end{array}$ & $\begin{array}{l}\text { Mundy and Chua, } 1988 \\
\text { Close et al, } 1989 \\
\text { Vilardell et al, } 1980 \\
\text { Baker et al, } 1988 \\
\text { Goday et al, } 1990\end{array}$ \\
\hline pcC3-06 & dsp 21 & $\begin{array}{l}\text { Group } 3 \text { Lea: } \\
\text { CD8 (carrot) } \\
\text { Group } 3 \text { Lea (wheat) } \\
\text { ABA-inducible gene (barley) }\end{array}$ & $\begin{array}{l}\text { Franz et al, } 1989 \\
\text { Curry and Walker-Simmons, } 1983 \\
\text { Hong et al, } 1988\end{array}$ \\
\hline pcC163 & - & Lea D29 (cotton) & Baker et al, 1988 \\
\hline pćC34-62 & - & $\begin{array}{l}\text { Lea D7 (cotton) } \\
\text { pLea } 76 \text { (Brassica) }\end{array}$ & $\begin{array}{l}\text { Baker et al, } 1988 \\
\text { Harada et al, } 1989\end{array}$ \\
\hline pcC26 & - & Lea D113 (cotton) & Baker et al, 1988 \\
\hline pcC27-45 & dsp 15 & Lea 14 (cotton) & Galau et al, 1993 \\
\hline $\mathrm{pcC} 11-24$ & dsp 68 & $\begin{array}{l}\text { LTI } 65 \text { (Arabidopsis) } \\
\text { rd29 (Arabidopsis) }\end{array}$ & $\begin{array}{l}\text { Nordin et al, } 1993 \\
\text { Yamaguchi-Shinozaki and Shino- } \\
\text { zaki, } 1993\end{array}$ \\
\hline $\mathrm{pcC} 13-62$ & dsp 34 & (Arabidopsis) & EMBL Data Library (Z17629) \\
\hline pcC37-31 & dsp 22 & $\begin{array}{l}\text { Elips (pea, barley) } \\
\text { cbr (Dunaliella) }\end{array}$ & $\begin{array}{l}\text { Grimm et al, } 1989 \\
\text { Kolanus et al, } 1987 \\
\text { Lers et al, } 1991\end{array}$ \\
\hline
\end{tabular}

${ }^{a}$ This list is incomplete due to the rapid accumulation of new sequences; ${ }^{b}$ the references for the Craterostigma cDNA clones are: Bartels et al, 1990; Piatowski et al, 1990; and Bartels et al, 1993.

One characteristic of the Lea proteins is that they accumulate in mature embryos during the onset of desiccation. They can be induced in premature embryos and in the vegetative tissues of plants by the plant hormone $A B A$. The occurrence of Lea proteins appears to be ubiquitous among plants and seems to be responsive to a wide range of osmotic stress forms (Skriver and Mundy, 1990; Bray, 1991). Most of the proteins are highly hydrophilic and they have been grouped into several classes according to their primary structure. Group 2 Lea is characterized by a stretch of serines and a lysine-rich repeat sequence. An 11-meramino-acid sequence motif is found repeated in tandem in group 3 Lea proteins (Dure et al, 1989). The high conservation of domains in these proteins suggests that they are functionally significant.

At least 8 desiccation-induced transcripts from Craterostigma can be assigned to different groups of Lea genes (table I). For some of the predicted proteins the homology was found to be only partial and restricted to the conserved domains, whereas in the case of pcC27-45 the encoded protein (dsp 15) was practically identical to the Lea 14 (Galau et al, 1993). Moreover, the group 2 Lea protein rab 17 has been shown to be phosphorylated in maize embryos (Vilardell et al, 1990). By in vivo labelling and immunoprecipitation, it was shown that the homologous protein in Craterostigma, dsp 16 , is also phosphorylated in desiccating Craterostigma leaves. The expression of different Lea-type genes in dehydrated vegetative tissues of Craterostigma suggests that the processes occurring in resurrection plants are at least in part similar to those occurring during the maturation of seeds in higher plants.

Homologies have also been found to the non-Lea-like transcripts. Clone pcC11-24 (dsp 68) has partial homology with an Arabidopsis cold and desiccation-inducible transcript (Nordin et al, 1993; YamagucchiShinozaki and Shinozaki, 1993) (table I). Clone pcC13-62 (dsp 34) has recently been found to be homologous to an unknown Arabidopsis transcript (table I). A different class 
of genes is represented by the clone pcC3731 (dsp 22). The predicted structure of this protein contains 3 hydrophobic domains, which are presumably membrane-spanning regions. The dsp 22 is closely related to Elipproteins (Elip = early light inducible protein), which accumulate in pea and barley during the transition from dark to light, and to a transcript associated with $\beta$-carotene biosynthesis in the salt-tolerant algae $D$ bardawil (Grimm et al, 1989; Kolanus et al, 1989; Lers et al, 1991).

The subcellular localization was studied for desiccation-related proteins in Craterostigma leaves. Immunogold electron microscopy revealed that dsp 68 ( $\mathrm{pcC11-24)}$ and all Leatype proteins were localized in the cytoplasm, with one exception, dsp 21 (pcC3-06), which was found in the stroma of chloroplasts. Two other proteins, dsp 22 and dsp 34, were found in chloroplasts associated with thylakoid membranes (Schneider et al, 1993). The chloroplastic association together with the homologies found between dsp 22 and Elips suggest a role of this class of desiccation-related proteins in the protection of the photosynthetic membranes.

The cytoplasmic proteins were present in all plant tissues tested (leaves, roots and seeds), whereas the chloroplastic proteins were found only in leaves, with the exception of dsp 21, which was also present in seeds (Bartels et al, 1992; Schneider et al, 1993).

The expression of the described desiccation-induced genes in Craterostigma can also be triggered by $A B A$, both in leaves and in callus (table II). In callus exogenous ABA treatment is necessary for the induction of these genes and is correlated with the tolerant phenotype. This indicates that $A B A$ is involved in mediating the expression of genes during dehydration.
Both callus and leaves showed an increase in the level of endogenous ABA during desiccation. However, the $A B A$ concentrations in callus never reached the levels found in leaves (Bartels et al, 1990), which could be an explanation why drying alone was not sufficient to induce gene expression in callus. Both ABA treatment and dehydration rapidly induced the expression of the water-stress proteins in leaves. However, no protein was found in callus in the cases of dsp 22 and dsp 21 (table II), probably because some chloroplastic components absent in callus are required for translation or stabilization of these proteins. Moreover, dsp 22 protein represents a particular case in which the induction with $A B A$ does not take place in the absence of light (Bartels et al, 1992). This result suggests that $A B A$ is important for the induction of the desiccation-related genes, but other environmental factors also modulate their expression.

To analyze $A B A$ inducibility of the dehydration-related genes in Craterostigma, promoter analysis was performed with the genomic clone corresponding to $\mathrm{pcC} 27-45$. A fragment 5 -upstream of the transcription start point $(-197$ to -542$)$ was shown to contain elements necessary for the $A B A$ inducibility in transient expression assays using the GUS reporter system (Michel et al, 1993). Interestingly, an ABA-inducible DNA binding activity located in this region has been found (Nelson et al, 1994).

\section{Barley embryos}

Barley embryos acquire desiccation tolerance, which can be described as the ability to germinate after a severe dehydration treatment. This property is developmentally regu-

Table II. Expression of desiccation-induced transcripts from Craterostigma

\begin{tabular}{lccccccc}
\hline cDNA clone & $\begin{array}{c}\text { Untreated } \\
\text { leaves }\end{array}$ & Dried leaves & $\begin{array}{c}\text { ABA-treated } \\
\text { leaves }\end{array}$ & $\begin{array}{c}\text { Untreated } \\
\text { callus }\end{array}$ & $\begin{array}{c}\text { Dried callus } \\
\begin{array}{c}\text { ABA-treated } \\
\text { callus }\end{array}\end{array} \begin{array}{c}\text { ABA-treated } \\
\text { dried callus }\end{array}$ \\
\hline pcC6-19 & + & +++ & +++ & + & + & +++ & +++ \\
pcC27-45 & - & +++ & +++ & - & - & ++ & +++ \\
pсC11-24 & - & +++ & +++ & - & - & ++ & +++ \\
pcC3-06 & - & +++ & +++ & - & - & + & ++ \\
pсC13-62 & - & +++ & +++ & - & - & ++ & ++ \\
pсC37-31 & - & +++ & ++ & - & - & - & + \\
\hline
\end{tabular}

${ }^{a}$ The amount of transcript correlates with the amount of protein in all cases, except for the chloroplastic proteins (pcC3-06, 13-62 and 37-81) in callus, in which the proteins were not detected or a very weak signal was found. 
lated and under our conditions embryos have acquired desiccation tolerance $18 \mathrm{~d}$ after pollination (dap) (Bartels et al, 1988). Several cDNA clones were isolated, which encode mRNAs expressed in 18 dap embryos, but not in younger ones (12 dap).

One of the clones isolated, pG30-44, belongs to the class of Lea transcripts (Velasco and Bartels, unpublished data); the DNA sequence of this cDNA is identical to the published sequences from wheat and barley (Litts et al, 1987; Espelund et al, 1992). A second clone (pG10-02) shows homology to glucose and ribitol dehydrogenase described in bacteria (Loviny et al, 1985; Heilmann et al, 1988; Alexander, 1992). Glucose dehydrogenase activity, which correlates with the expression of this protein, has been found in crude extracts of 18 dap embryos.

The clone pG22-69, which is related to the aldo-keto reductase superfamily, has been analyzed in more detail. In animal tissues, the expression of aldose reductases is induced by increasing external osmotic pressure (Bedford et al, 1987; Burg, 1988). The enzyme is responsible for the production of sorbitol, a potential osmolyte, during such a stress conditions.

In 18 dap embryos both aldose reductase activity and the pG22-69 product were detected. In order to analyze the enzymatic properties of this protein, the full length cDNA clone was expressed in Escherichia coli and purified using metal ion affinity chromatography. The recombinant enzyme showed aldose reductase activity. To further characterize the barley enzyme, site-directed mutagenesis on the cDNA was used to substitute a lysine with a methionine residue. The lysine residue is part of the highly conserved tetrapeptide Ile-ProLys-Ser and has been speculated to be essential for catalytic activity (Bohren et al, 1989).

The wild-type enzyme can reduce D,L-glyceraldehyde more efficiently than the mutant one. However, the observed $K_{\mathrm{m}}$ values are higher when compared with animal aldose reductases (Roncarati and Bartels, manuscript in preparation).

To characterize the regulation of this gene, promoter studies were carried out using the GUS-reporter system. The experiments showed that a genomic upstream fragment, spanning position -113 to +76 is sufficient to direct GUS expression in seeds of tobacco transgenic plants (Roncarati and Bartels, manuscript in preparation). The GUS product appears 18-20 dap and increases during seed maturation, thus following the same pattern of expression as the gene in barley embryos. Furthermore, this proximal promoter fragment is about 10 -fold more active than the longest $(1.4 \mathrm{~kb})$ upstream region tested.

\section{CONCLUSIONS}

The analysis of gene expression during dehydration in 2 desiccation-tolerant systems (resurrection plants and developing embryos of higher plants) indicates that the pathways leading to water-stress tolerance are very similar in both systems. Moreover, many of the gene products accumulating during dehydration are homologous in seeds and resurrection plants. This suggests that the genetic information needed for the development of tolerance to cellular dehydration is present in several higher plants. The restriction of the tolerance to the seeds in the majority of plants probably reflects the complexity of vegetative tissues compared with resting embryos. Additional components (eg, osmolytes and channel proteins) are probably needed in vegetative tissues to both obtain the tolerance and resume cellular functions upon rehydration.

\section{REFERENCES}

Alexander R (1992) Untersuchungen zur Genexpression in Gerstenembryonen während der Ausbildung der Trockentoleranz. PhD Thesis, University of Cologne, Germany

Baker JC, Steele C, Dure III L (1988) Sequence and characterization of 6 Lea proteins and their genes from cotton. Plant Mol Biol, 11, .277-291

Bartels D, Singh M, Salamini $F$ (1988) Onset of desiccation tolerance during development of the barley embryo. Planta 175, 485-492

Bartels D, Schneider K, Terstappen G, Piatkowski $D$, Salamni $F$ (1990) Molecular cloning of ABAmodulated genes from the resurrection plant Craterostigma plantagineum which are induced during desiccation. Planta 181, 27-34

Bartels D, Schneider K, Piatkowski D et al (1991) Molecular analysis of desiccation tolerance in the resurrection plant Craterostigma plantagineum. VI NATO Adv Study Inst Plant Mol Biol (RG Herrmann, B Larkins, eds) 663-671

Bartels D, Hanke C, Schneider $K$, Michel D, Salamini F (1992) A desiccation-related Elip- 
like gene from the resurrection plant Craterostigma plantagineum is regulated by light and ABA. EMBO J 11, 2771-2778

Bartels D, Velasco R, Schneider K, Forlani F, Furini A, Salamini F (1993) Resurrection plants as model systems to study desiccation tolerance in higher plants. In: Biotechnology for Arid land plants ( $T$ Mabry, $\mathrm{H}$ Nguyen, R Dixon, MS Bonness, eds) 47-58

Bedford KM, Bagnasco SM, Kador PF, Harris WH, Burg MB (1987) Characterization and purification of a mammalian osmoregulatory protein, aldose reductase, induced in renal medulary cells by high extracellular $\mathrm{NaCl}$. J Biol Chem 262, 14255-14259

Bohren KM, Bullock B, Wermuth B, Gabbay KH (1989) The aldo-keto reductase superfamily. cDNAs and deduced amino-acid sequences of human aldehyde and aldose reductases. $J$ Biol Chem 264, 9547-9551

Bray E (1991) Regulation of gene expression by endogenous ABA during drought stress. In: $A b$ scisic Acid Physiology and Biochemistry (WJ Davies, HG Jones, eds) Bios scientific Publishers, Oxford, UK

Burg M (1988) Role of aldose reductase and sorbitol in maintaining the medullary intracellular milieu. Kidney Int 33, 635-641

Close TJ, Kortt AA, Chandler PM (1989) A cDNAbased comparison of dehydration-induced proteins (dehydrins) in barley and corn. Plant Mol Biol 13, 95-108

Curry J, Walker-Simmons MK (1993) Unusual sequence of group 3 Lea (II) mRNA inducible by dehydration stress in wheat. Plant Mol Biol 21, 907-912

Dure III L, Crouch M, Harada J et al (1989) Common amino-acid sequence domains among the Lea proteins of higher plants. Plant $\mathrm{Mol} \mathrm{Biol}$ $12,475-486$

Espelund M, Saeboe-Larssen S, Hughes DW, Galau GA, Larsen F, Jakobsen KS (1992) Late embryogenesis-abundant genes encoding proteins with different numbers of hydrophilic repeats are regulated differentially by abscisic acid and osmotic stress. Plant $J 2,241-252$

Franz G, Hatzopoulos P, Jones TJ, Krauss $M$, Sung ZR (1989) Molecular and genetic analysis of an embryonic gene, DC8, from Daucus carota L. Mol Gen Genet 218, 143-151

Gaff DF (1971) Desiccation-tolerant flowering plants in Southern Africa. Science 174, 10331034

Gaff DF (1981) The biology of resurrection plants. In: The Biology of Australian Plants (JS Plate, AJ McComb, eds) Nedland, University of Western Australia Press, 114-146
Galau GA, Hughes DW, Dure III L (1986) Abscisicacid induction of cloned cotton late embryogenesis abundant (Lea) mRNAs. Plant Mol Biol 7, 155-170

Galau GA, Wang H, Hughes DW (1993) Cotton Lea 5 and Lea 14 encode atypical late-embryogenesis abundant proteins. Plant Physiol 101, 695-696

Goday JA, Pardo JM, Pinto-Toro JA (1990) A cDNA inducible by salt stress and abscisic acid: nucleotide sequence and expression pattern. Plant Mol Biol 15, 685-705

Grimm B, Kruse E, Kloppstech K (1989) Transiently expressed early light-inducible thylakoid proteins share transmembrane domains with light-harvesting chlorophyll binding proteins. Plant Mol Biol 13, 583-593

Harada JJ, DeLisle AJ, Baden CS, Crouch ML (1989) Unusual sequence of an abscisic acidinducible mRNA which accumulates late in Brassica napus seed development. Plant $\mathrm{Mol}$ Biol 12, 395-401

Heilmann HJ, Mägert HJ, Gassen HG (1988) Identification and isolation of glucose dehydrogenase genes of Bacillus megaterium M1286 and their expression in Escherichia coli. Eur $J$ Biochem 174, 485-490

Hong B, Uknes SJ, Ho TD (1988) Cloning and characterization of a cDNA encoding mRNA rapidly induced by $A B A$ in barley aleurone layers. Plant Mol Biol 11, 495-506

Kolanus W, Scharnhorst C, Kühne K, Herzfeld F (1987) The structure and light-dependent transient expression of a nuclear-encoded chloroplast protein gene from pea. Mol Gen Genet 209, 234-239

Lers A, Levy $H$, Zamir A (1991) Co-regulation of a gene homologous to early light-induced genes in higher plants and $\beta$-carotene biosynthesis in the alga Dunaliella bardawil. $J$ Biol Chem 266, 13698-13705

Litts JC, Colwell GC, Chakherian RL, Quatrano RS (1987) The nucleotide sequence of a cDNA clone encoding the wheat $\mathrm{Em}$ protein. Nucl Acids Res 15, 3606-3618

Loviny T, Norton PM, Hartley BS (1985) Ribitol dehydrogenase of Klebsiella aerogenes. Biochem J 230, 579-585

Michel D, Salamini F, Bartels D, Dale P, Baga M, Szalay A (1993) Analysis of a desiccation and ABA-responsive promoter isolated from the resurrection plant Craterostigma plantzagineum. Plant J 4, 29-40

Mundy J, Chua NH (1988) Abscisic acid and water stress induce the expression of a novel rice gene. EMBO J 7, 2279-2286

Nelson D, Salamini F, Bartels D (1994) Abscisic acid promotes novel DNA-binding activity to a 
desiccation-related promotes of Craterostigma plantagineum. Plant $J 5$ (in press)

Nordin K, Vahala T, Palva ET (1993) Differential expression of two related, low-temperature-induced genes in Arabidopsis thaliana (L) Heynh. Plant Mol Biol 21, 641-563

Piatkowski D, Schneider K, Salamini F, Bartels D (1990) Characterization of five abscisic acid-responsive cDNA clones isolated from the desiccation-tolerant plant Craterostigma plantagineum and their relationship to other waterstress genes. Plant Physiol 94, 1682-1688

Schneider K, Wells B, Schmelzer E, Salamini F, Bartels D (1993) Desiccation leads to the rapid accumulation of both cytosol and chloroplastic proteins in the resurrection plant Craterostigma plantagineum Hochst. Planta 189, 120-131

Skriver K, Mundy J (1990) Gene expression in response to abscisic acid and osmotic stress. Plant Cell 2, 503-512

Vilardell J, Goday A, Freire MA, Torrent M, Martínez C, Torne JM, Pagés M (1990) Gene sequence, developmental expression and protein phosphorylation of rab 17 in maize. Plant Mol Biol 14, 423-432

Yamaguchi-Shinozaki K, Shinozaki K (1993) Characterization of the expression of desiccation-responsive rd29 gene of Arabidopsis thaliana and analysis of its promoter in transgenic plants. Mol Gen Genet 236, 331-340 